\title{
Distribution of Tick Species Infesting Domestic Ruminants in Borderline of Iran-Afghanistan
}

\author{
Ahmad Jafarbekloo', Hassan Vatandoost ${ }^{2}$, Alireza Davari², Faezeh Faghihi' ${ }^{3}$, \\ Hasan Bakhshi², Maryam Roya Ramzgouyan ${ }^{4}$, Mohammad Nasrabadi², \\ Zakkyeh Telmadarraiy ${ }^{2 *}$ \\ ${ }^{1}$ School of Medicine, Tehran University of Medical Sciences (TUMS), Tehran, Iran \\ ${ }^{2}$ School of Public Health, Tehran University of Medical Sciences (TUMS), Tehran, Iran \\ ${ }^{3}$ Depatment of Tissu Engineering, Iran University of Medical Sciences (IUMS), Tehran, Iran \\ ${ }^{4}$ School of Advanced Technologies in Medicine, Tehran University of Medical Sciences (TUMS), Tehran, Iran \\ Email: zztelma@yahoo.co.in, telmadarraiy@tums.ac.ir
}

Received 11 August 2014; revised 27 September 2014; accepted 11 October 2014

Copyright (C) 2014 by authors and Scientific Research Publishing Inc.

This work is licensed under the Creative Commons Attribution International License (CC BY).

http://creativecommons.org/licenses/by/4.0/

c) (i) Open Access

\section{Abstract}

To determine the tick species parasitizing domestic ruminants in Zabol, Zahak and Qaen Counties which are located in east of Iran and are bordered with Afghanistan country, about 73 sheep, 44 goats and 27 cattle of 12 herds in several villages in Zabol, Zahak and Qaen Counties were inspected for tick infestation. Separated ticks were preserved in $70 \%$ alcohol and identified. About 464 ticks (252 male; 194 female) were collected; the occurrences of ticks on goats, cattle and sheep were about $17 \%, 15 \%$ and $26 \%$ respectively in all three Counties. The mean number of ticks on each animal was about 2 - 7 ticks per animal. Totally we found 3 genera hard ticks including Hyalomma, Rhipicephalus and Dermacentor in these regions. Hyalomma anatolicum, Hy. marginatum, Hy. asiaticum, Hy. detrinium, Rhipicephalus bursa, $R$. sanguineus, Dermacentorniveus, and $D$. marginatus, were the tick species we found. Hyalomma anatolicum and Hy. asiaticum were the most abundant species in the study area. The result of this study is a survey of tick species from domestic animals in east part of Iran and implication of possible prevention measures for diseases transmitted by ticks.

\section{Keywords}

Tick, Ruminants, Borderline, Iran, Afghanistan

\footnotetext{
${ }^{*}$ Corresponding author.
}

How to cite this paper: Jafarbekloo, A., Vatandoost, H., Davari, A., Faghihi, F., Bakhshi, H., Ramzgouyan, M.R., Nasrabadi, M. and Telmadarraiy, Z. (2014) Distribution of Tick Species Infesting Domestic Ruminants in Borderline of Iran-Afghanistan. J. Biomedical Science and Engineering, 7, 982-987. http://dx.doi.org/10.4236/jbise.2014.712095 


\section{Introduction}

Ticks can transmit a variety of diseases such as Crimean Congo hemorrhagic fever, anaplasmosis, babesiosis, rickettsiosis, borreliosis and ehrlichiosis. Symptoms of these parasites vary from minor itching and irritation to extreme annoyance and fatigue, malnutrition and even death by infection to the parasites which are transmitted by ticks. Such diseases are considered as public health or veterinary problems in the communities. Fortunately, many control options are available to help farmers manage livestock. Tick species distribution in Iran is briefly reviewed on the basis of published records.

Tick studies were initiated by Delpy in Iran. Later, Abbasian-Lintzen and Mazlum compiled a list of adult ticks collected from domestic animals. Filippova et al. presented data for 642 ixodid ticks taken from smallsized mammals, mainly rodents in different zoogeographical zones of Iran. Hoogstral and Wassef studied ixodid ticks parasitizing wild sheep and goats in Iran focusing on maintaining natural foci of many hazardous diseases for human. Telmadarraiy et al. published a list of tick species and their prevalence in the northwest and the western part of the country [1]-[3]. Rahbari et al. published a primary report on distribution of various species of ticks on domestic animals in four geographical areas of Iran [4]. There are several reports on epidemiology, distribution, medical importance and susceptibility of different ticks through the country [2] [5]-[9]. The occurrence of nine ixodid tick species was determined from Qazvin province, Iran [10].

In another study in Qaemshahr region in Iran, Rhipicephalus sanguineus was the most abundant species in the study area [11]. Recently Sarani et al., studied on distribution of ticks infesting domestic ruminants in Golestan province, Iran. They found five species of ixodid ticks in that region [12].

Since, thus far, only a few studies have been accomplished about the tick fauna in different areas of Iran, there still seems to be a gap in our knowledge about distribution of tick species in the country. Further, there is a lack of finding about the frequency of tick species from domestic ruminants in east part of Iran. Therefore, this study is aimed to figure out the frequency of ticks on domestic ruminants in Zabol, Zahak and Qaen counties which are located in east of Iran and are bordered with Afghanistan country.

Approximately $10 \%$ of the currently known 867 tick species act as vectors of a broad range of pathogens of domestic animals and humans and are also responsible for damage directly due to their feeding behavior [13]. Ruminants are also affected by direct tick damage including tick bite abscesses, tick paralysis, tick-induced dermatophilosis, etc. This present study is aimed at the survey of tick species in cattle, goats and sheep in Zabol, Zahak and Qaen Counties.

\section{Materials and Methods}

Our survey was carried out in Zabol County and Zahak County which are located in Sistan and Baluchestan province and also in Qaen County which is located in South Khorasan province. These two provinces are located in east of Iran and are bordered with Afghanistan country (Figure 1). Qaen County is a county in South Khorasan Province. The capital of the county is Qaen. The county's population is about 137,000 in 35,000 fami-

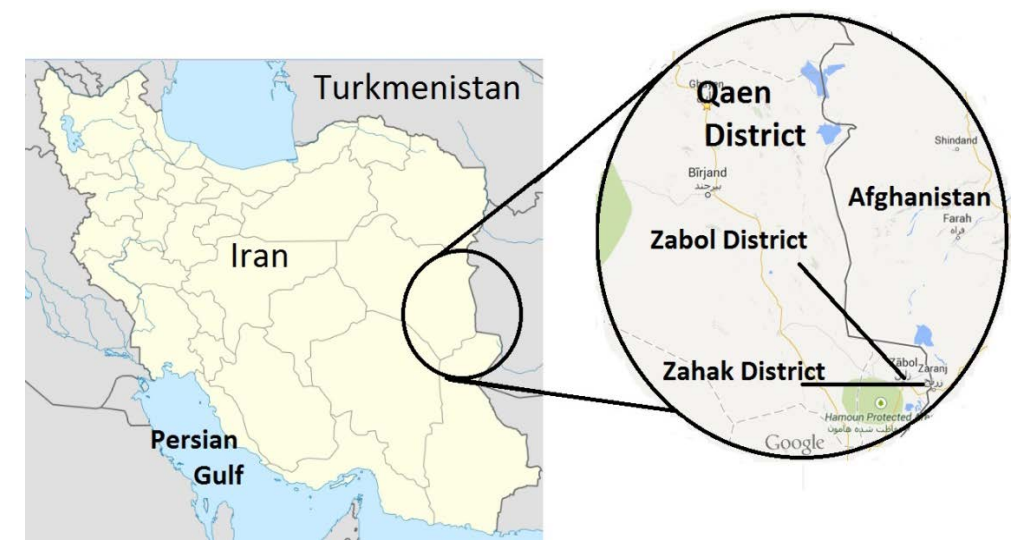

Figure 1. Map of Iran showing our study areas which are magnified. Qaen, Zahak and Zabol Counties are located in east of Iran and are bordered with Afghanistan. 
lies. Zabol and Zahak Counties have a population about 300,000 in 67,000 families and 70,000 in 14,000 families respectively.

Samples collection: From June 2012 to May 2013, We tried to catch ticks from goats, cows and sheep from Tigab, Mahdi Abad, Farokhi and Pahnayi districts, in Qaen County, Hossein Abad, Heydar Abad, Fathollah and Bagher Abad which are located in Zabol County and Khomak, Bonjar and Hassankhoon which are located in Zahak County (Figure 1). Ticks were mostly found on shoulders and ears of the livestock. In total, 144 animals from 12 herds including 73 sheep, 44 goats and 27 cattle were selected randomly and examined individually for tick infestation. Thirty minutes were spent for each flock to collect ticks. All inspections and tick collections were carried out between 08:00 a.m. and 11:00 a.m. In case of infestation, ticks were collected using forceps and then preserved in 70\% ethyl alcohol. All collected specimens were preserved in tubes and relative information was recorded. Specimens were transferred to the Entomology Laboratory, School of Public Health, Tehran University of Medical Sciences. All specimens were identified based on morphological characteristics and the keys given by Janbakhsh (1957) [14] and Walker (2003) [15] based on shape of capitulum, scutum, eyes, festoone and hypostome, spiracle, genital groove, spure of coxa, adanal shield and another characters; so these keys were used to identify each tick to species.

\section{Results}

Totally 446 ticks were collected and the occurrence of ticks on goats, cattle and sheep were about $17 \%, 15 \%$ and $26 \%$ respectively in all three study areas The mean number of ticks on each animal was about 2 - 7 ticks per animal. Totally we identified 3 genus in study areas. Hyalomma and Rhipicephalus genus found in all three counties. Also we found Dermacentor genus, just in Qaen County. The results revealed that Qaen County had the most species diversity by 8 species in 3 genera. Details of the specimens are available in Table 1 . The results showed that 311 out of 446 (69.7\%) of all collected ticks were caught from Qaen County. Out of these 311 collected ticks, Hy. anatolicum was the most abundant (30.9\%) tick in Qaen County and all three counties (13\%).

Collected ticks from Qaen County revealed that most of the caught ticks from each species were male except R. bursa. We found 3 species from 2 genus in Zabol County. Out of 446 collected samples, 76 of them (17\%) were caught from Zabol County. These 76 samples belonged to 3 species in 2 genera. Finally we found only 59 tick samples in Zahak County. We found only 2 genus and three species in Zahak County. Totally 59 specimens (13.2\%) were collected from this area. The prevalence of ticks in Qaen County was more than two other Counties.

\section{Discussion}

As ticks are very important vectors of human and animal diseases, they are subject of many studies in Iran. There is very limited information about geographical distribution of tick infestation in a certain geographical areas, especially in Iran [12].

Our results demonstrate 8 tick species from 3 genera. They infest domestic ruminants in East part of Iran which is bordered with Afghanistan country. Most of ticks (69.7\%) were collected from Qaen district. The number

Table 1. Details of caught ticks of Qaen County from South Khorasan Province and Zahak and Zabol Counties from Sistan and Baluchestan Province. Totally 446 ticks collected from these 3 study area.

\begin{tabular}{|c|c|c|c|c|c|c|c|}
\hline \multirow{2}{*}{ Species } & \multicolumn{2}{|c|}{ Qaen } & \multicolumn{2}{|c|}{ Zahak } & \multicolumn{2}{|c|}{ Zabol } & \multirow{2}{*}{ Total } \\
\hline & Male & Total & Male & Total & Male & Total & \\
\hline Hy. anatolicum & 83 & 138 & 12 & 22 & 20 & 36 & 196 \\
\hline Hy. asiaticum & 44 & 78 & 8 & 16 & 3 & 14 & 108 \\
\hline$R$. sanguineus & 8 & 14 & 9 & 21 & 11 & 26 & 61 \\
\hline Hy. marginatum & 25 & 33 & & & & & 33 \\
\hline Hy. detrinium & 9 & 21 & & & & & 21 \\
\hline D. marginatus & 11 & 13 & & & & & 13 \\
\hline D. niveus & 5 & 9 & & & & & 9 \\
\hline R. bursa & 4 & 5 & & & & & 5 \\
\hline Total & 189 & 311 & 29 & 59 & 34 & 76 & 446 \\
\hline
\end{tabular}


of collected ticks in Zabol district was 76 ticks (17\%); also the number of collected ticks in Zahak district was 59 (13.2\%); so the number of ticks in these two districts was very low. The most abundant species in our investigation belongs to $H$. anatolicum with a prevalence of $43.9 \%$ in all collected specimens. This is a very important point due to this fact that $H$. anatolicum has been incriminated as a vector of Crimean-Congo hemorrhagic fever in Hamadan, Iran [16]. The prevalence of this tick in Qaen, Zahak and Zabol is 44.3, 37.2 and 47.3 percent respectively; so this shows that $H$. anatolicum may transmit Crimean-Congo hemorrhagic fever in all 3 districts. The other abundant caught tick belongs to $H$. asiaticum with a prevalence of $24.2 \%$ in all collected specimens. The prevalence of $H$. asiaticum in Qaen, Zahak and Zabol districts is $25 \%, 27.1 \%$ and $18.4 \%$ respectively. This was in agreement with studies which demonstrated that $H$. asiaticum was the second abundant tick infesting sheep (48.5\%) in south Khorasan province and H. anatolicum was the most frequent species with $71.5 \%$ of the ticks of Domestic Ruminants in the Southern Khorasan-e-Razavi province, Iran [17] [18]. In a recent investigation in Iran, $H$. anatolicum and $H$. asiaticum were found with a prevalence of $5.9 \%$ and $3.9 \%$ respectively, in mountainous areas of Golestan province, north of Iran [12]; a similar prevalence was reported in investigations in Mazandaran Provice (north of Iran) and Yazd province (center of Iran) [2] [19], whereas H. anatolicum was the infrequent species with prevalence of $0.4 \%$ among collected species in Qazvin province [10]. We collected $H y$. anatolicum, Hy. marginatum, Hy. asiaticum, Hy. detrinium, $R$. bursa, $R$. sanguineus, $D$. niveus, and $D$. marginatus in Qaen district; while we could just find Hy. anatolicum, Hy. asiaticum and R. sanguineus in Zahak county and in Zabol county. Our results show that $H$. anatolicum, H. asiaticum and $R$. sanguineus are found in all of our study areas. These ticks infest domestic ruminants in Zabol, Zahak and Qaen.

The brown dog tick, $R$. sanguineus, was the third frequent collected tick in our study. The prevalence of this tick in all collected samples was 13.6\%. The prevalence of this tick in Qaen, Zahak and Zabol districts was 4.5\%, $35.5 \%$ and $34.2 \%$ respectively. This tick is widely distributed around the world and it has been collected widely across the country [4]. This tick was the most frequent and abundant species with prevalence of $66.7 \%$ in Golestan province [12], while it was found with prevalence of $14.06 \%$ from Golestan province [20]; also in a study by sofizadeh et al., $R$. sanguineus was the most abundant species in that study area [21]. This tick commonly infests dogs and it can also feed on other animals and man [22].

In this study, we collected 5 species from Qaen County, which were not seen in Zahak County and Zabol County. The prevalence of Hy. marginatum, Hy. detrinium, D. marginatus, D. niveus and Rhipicephalus bursa in Qaen collected specimens was $10.6 \%, 6.7 \%, 4.1 \%, 2.8 \%$ and $1.6 \%$ respectively. Recently, we have investigated on infection of ticks to Anaplasma and Ehrlichia pathogens in Zabol and Zahak County in Sistan and Baluchestan Province which are bordered with Afghanistan. Molecular studies on these samples showed that Ehrlichia's DNA and Anaplasma's DNA were found in $26.4 \%$ of collected ticks [23]. The results showed the infection of Rhipicephalus sanguineus and Hyalomma anatolicum with Anaplasmaovis. Also we saw infection of $H$. anatolicum and H. asiaticum ticks to Ehrlichiaspp [23]. These results demonstrate the infection of ticks collected from livestock in borderline of Iran-Afghanistan; so application of control measures with emphasis on control of $R$. sanguineus could prevent Anaplasma transmission in this region.

The tick infestation has thus been shown to occur in different areas of Iran, and this may indicate that special attention should be directed to certain areas concerning certain ticks [11]. A long time has passed since the previous studies on tick fauna in Iran, and the intensity of livestock has been changing in different places. Together with climatic changes of recent years, these factors can influence the diversity of ticks in Iran, and it is planned to apply new suggested key criteria and biological methods to investigate tick species in Iran.

\section{Acknowledgements}

This study has been done by financial supports of Tehran University of Medical Sciences.

\section{References}

[1] Telmadarraiy, Z., Bahrami, A. and Vatandoost, H. (2004) A Survey on Fauna of Ticks in West Azerbaijan Province, Iran. Iranian Journal of Public Health, 33, 65-69.

[2] Telmadarraiy, Z., Ghiasi, S.M., Moradi, M., Vatandoost, H., Eshraghian, M.R., Faghihi, F., Zarei, Z., Haeri, A. and Chinikar, S. (2010) A Survey of Crimean-Congo Haemorrhagic Fever in Livestock and Ticks in Ardabil Province, Iran during 2004-2005. Scandinavian Journal of Infectious Diseases, 42, 137-141.

http://dx.doi.org/10.3109/00365540903362501 
[3] Telmadarraiy, Z., Moradi, A., Vatandoost, H., Mostafavi, E., Oshaghi, M., Zahimia, A., Haeri, A. and Chinikar, S. (2008) Crimean-Congo Hemorrhagic Fever: A Seroepidemiological and Molecular Survey in Bahar, Hamadan Province of Iran. Asian Journal of Animal \& Veterinary Advances, 3, 321-327.

[4] Rahbari, S., Nabian, S. and Shayan, P. (2007) Primary Report on Distribution of Tick Fauna in Iran. Parasitology Research, 101, 175-177. http://dx.doi.org/10.1007/s00436-007-0692-7

[5] Aghighi, Z., Assmar, M., Piazak, N., Javadian, E., Seyedi-Rashti, M., Kia, E., Rassi, Y. and Vatandoost, H. (2007) Distribution of Soft Ticks and Their Natural Infection with Borrelia in a Focus of Relapsing Fever in Iran. Journal of Arthropod-Borne Diseases, 1, 14-18.

[6] Kia, E., Moghddas-Sani, H., Hassanpoor, H., Vatandoost, H., Zahabiun, F., Akhavan, A., Hanafi-Bojd, A. and Telmadarraiy, Z. (2009) Ectoparasites of Rodents Captured in Bandar Abbas, Southern Iran. Journal of Arthropod-Borne Diseases, 3, 44.

[7] Masoumi Asl, H., Goya, M., Vatandoost, H., Zahraei, S., Mafi, M., Asmar, M., Piazak, N. and Aghighi, Z. (2009) The Epidemiology of Tick-Borne Relapsing Fever in Iran during 1997-2006. Travel Medicine and Infectious Disease, 7, 160-164. http://dx.doi.org/10.1016/j.tmaid.2009.01.009

[8] Telmadarraiy, Z., Nasirian, H., Vatandoost, H., Abuolhassani, M., Tavakoli, M., Zarei, Z., Banafshi, O., Rafinejad, J., Salarielac, S. and Faghihi, F. (2007) Comparative Susceptibility of Cypermethrin in Ornithodoros lahorensis Neuman and Argas persicus Oken (Acari: Argasidae) Field Populations. Pakistan Journal of Biological Sciences, 10, 43154318. http://dx.doi.org/10.3923/pjbs.2007.4315.4318

[9] Telmadarraiy, Z., Vatandoost, H., Mohammadi, S., Akhavan, A., Abai, M., Rafinejad, J., Kia, E., Naini, F.F. and Jedari, M. and Aboulhasani, M. (2007) Determination of Rodent Ectoparasite Fauna in Sarpole-Zahab District, Kermanshah Province, Iran, 2004-2005. Journal of Arthropod-Borne Diseases, 1, 58-62.

[10] Shemshad, K., Rafinejad, J., Kamali, K., Piazak, N., Sedaghat, M., Shemshad, M., Biglarian, A., Nourolahi, F., Valadbeigi, E. and Enayati, A. (2012) Species Diversity and Geographic Distribution of Hard Ticks (Acari: Ixodoidea: Ixodidae) Infesting Domestic Ruminants, in Qazvin Province, Iran. Parasitology Research, 110, 373-380. http://dx.doi.org/10.1007/s00436-011-2501-6

[11] Nasibeha, H.V., Zakkyeha, T., Hassana, V., Rezaa, Y.E.M., Mortezab, H.V. and Alia, O.M. (2010) Survey of Tick Species Parasiting Domestic Ruminants in Ghaemshahr County, Mazandaran Province, Iran. Asian Pacific Journal of Tropical Medicine, 3, 804-806. http://dx.doi.org/10.1016/S1995-7645(10)60193-9

[12] Sarani, M., Telmadarraiy, Z., Moghaddam, A.S., Azam, K. and Sedaghat, M. (2014) Distribution of Ticks (Acari: Ixodidae) Infesting Domestic Ruminants in Mountainous Areas of Golestan Province, Iran. Asian Pacific Journal of Tropical Biomedicine, 4, S246-S251.

[13] Jongejan, F. and Uilenberg, G. (2004) The Global Importance of Ticks. Parasitology, 129, S3-S14. http://dx.doi.org/10.1017/S0031182004005967

[14] Janbakhsh, B. (1957) A Research Review about Ticks Responsible for Relapsing Fever in Iran. Journal of Faculty of Health and Institute of Public Health and Research, 484, 223-230.

[15] Walker, A., Bouattour, A., Camicas, J., Estrada-Pena, A., Horak, I., Latif, A., Pegram, R. and Preston, P. (2003) Ticks of Domestic Animals in Africa: A Guide to Identification of Species. Bioscience Reports, Edinburgh.

[16] Tahmasebi, F., Ghiasi, S., Mostafavi, E., Moradi, M., Piazak, N., Mozafari, A., Haeri, A., Fooks, A. and Chinikar, S. (2010) Molecular Epidemiology of Crimean-Congo Hemorrhagic Fever Virus Genome Isolated of Ticks from Hamadan Province of Iran. Journal of Vector Borne Diseases, 47, 211-216.

[17] Razmi, G., Eshrati, H. and Rashtibaf, M. (2006) Prevalence of Theileria spp. Infection in Sheep in South Khorasan Province, Iran. Veterinary Parasitology, 140, 239-243. http://dx.doi.org/10.1016/j.vetpar.2006.04.002

[18] Riabi, H. and Atarodi, A. (2014) Faunistic Study of Hard Ticks (Ixodidae) of Domestic Ruminants in the Southern Khorasan-e-Razavi in Comparing with Other Regions of the Province in 2012 Iran. Journal of Veterinary Advances, 4, 508-515.

[19] Razmi, G., Glinsharifodini, M. and Sarvi, S. (2007) Prevalence of Ixodid Ticks on Cattle in Mazandaran Province, Iran. The Korean Journal of Parasitology, 45, 307-310. http://dx.doi.org/10.3347/kjp.2007.45.4.307

[20] Nabian, S., Rahbari, S., Shayan, P. and Haddadzadeh, H. (2007) Current Status of Tick Fauna in North of Iran. Iranian Journal of Parasitology, 2, 12-17.

[21] Sofizadeh, A., Telmadarraiy, Z., Rahnama, A., Gorganli-Davaji, A. and Hosseini-Chegeni, A. (2013) Hard Tick Species of Livestock and Their Bioecology in Golestan Province, North of Iran. Journal of Arthropod-Borne Diseases, 8, 108.

[22] Evans, D., Martins, J. and Guglielmone, A. (2000) A Review of the Ticks (Acari, Ixodida) of Brazil, Their Hosts and Geographic Distribution-1. The State of Rio Grande do Sul, Southern Brazil. Memórias do Instituto Oswaldo Cruz, 95, 453-470. http://dx.doi.org/10.1590/S0074-02762000000400003 
[23] Jafarbekloo, A., Bakhshi, H., Faghihi, F., Telmadarraiy, Z., Khazeni, A., Oshaghi, M.A., Ramzgouyan, M.R. and Sedaghat, M.M. (2014) Molecular Detection of Anaplasma and Ehrlichia Infection in Ticks in Borderline of Iran-Afghanistan. Journal of Biomedical Science and Engineering, 7, 919-926. http://dx.doi.org/10.4236/jbise.2014.711089 
Scientific Research Publishing (SCIRP) is one of the largest Open Access journal publishers. It is currently publishing more than 200 open access, online, peer-reviewed journals covering a wide range of academic disciplines. SCIRP serves the worldwide academic communities and contributes to the progress and application of science with its publication.

Other selected journals from SCIRP are listed as below. Submit your manuscript to us via either submit@scirp.org or Online Submission Portal.
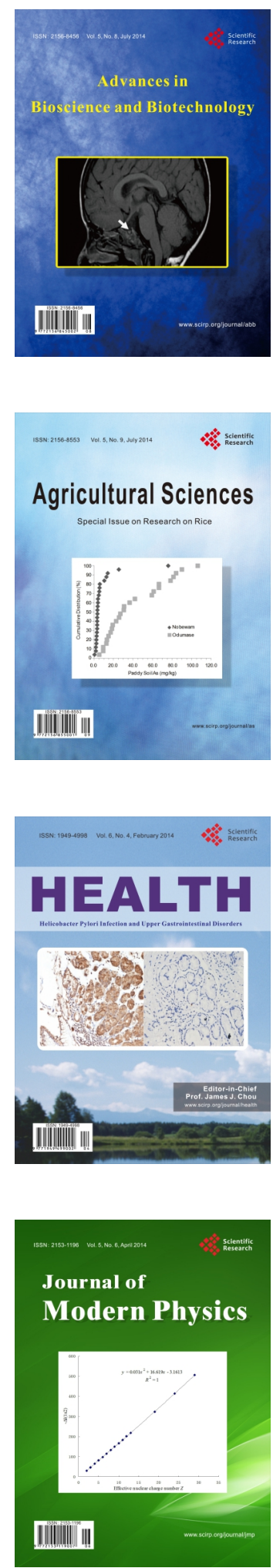
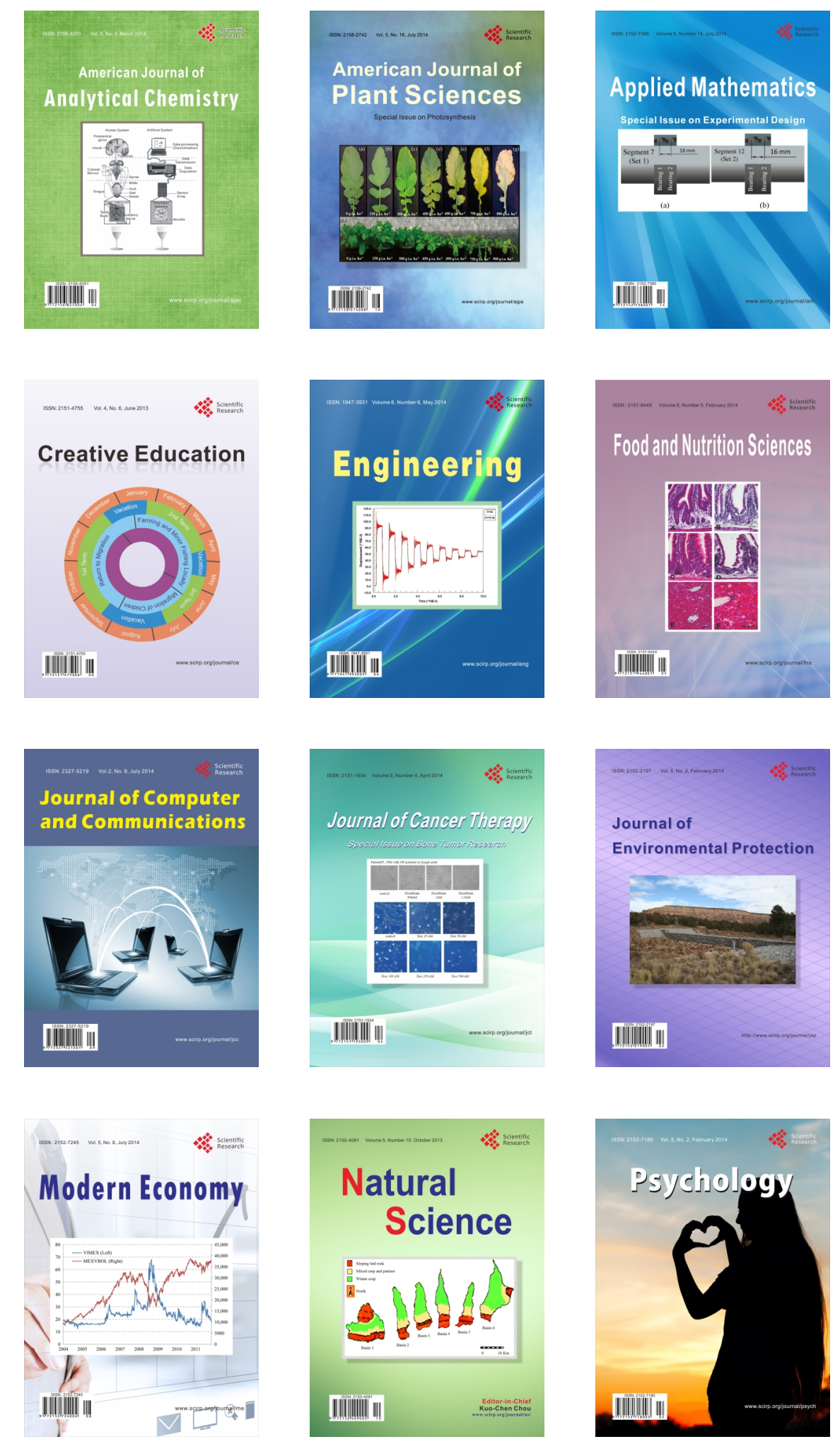